\title{
Mexican Immigrant Families Under Siege: The Impact of Anti-Immigrant Policies, Discrimination, and the Economic Crisis
}

\author{
Cecilia Ayón \\ David Becerra
}

\begin{abstract}
Latino immigrants have historically faced many challenges living in the United States. The economic crisis combined with new anti-immigration policies and harsh enforcement strategies may exacerbate the stress and anxiety Latino immigrant families already endure as a result of discrimination and financial hardships. The purpose of this study was to understand the current challenges Latino immigrant families encounter within an anti-immigrant socio-political environment. Fifty-two first generation immigrants participated in focus group sessions, which lasted between 90 and 120 minutes. The findings revealed that the economic crisis, anti-immigration policies, and enforcement strategies have had deleterious effects on Latino immigrant families' wellbeing. Participants stated that their limited English proficiency and racial profiling were the basis for the discriminatory practices they endured. Discrimination was experienced through instances of micro-aggression, as well as horizontal discrimination and institutional discrimination. Implications for social policy, social work practice, and research are discussed.
\end{abstract}

Keywords: Latino families, immigration policy, discrimination, economic crisis

Over the past several decades, numerous factors have influenced the rise of antiimmigrant sentiment and an increase in anti-immigrant policies in the United Stated During the last century, wars have led to anti-immigrant policies and discrimination of Japanese, Korean, Vietnamese, and most recently Arabs and Muslims in the United States. Economic issues also contribute to anti-immigrant policies and discrimination. Although immigrants have historically filled the demand for labor in the U.S., during times of economic hardship and high unemployment, immigrants are often used as scapegoats and blamed for taking jobs away from "real" Americans. The economic recessions of 1990-1991, 2001, and 2007-2009 have contributed to the current antiimmigrant sentiment and the increase in anti-immigrant policies against Latino immigrants in the United States (Becerra, 2012). Such policies directly impact Latinos who represent $16 \%$ (or 50.5 million) of the U.S. population (Humes, Jones, \& Ramirez, 2011), of whom it is estimated 18 million are immigrants (Grieco, 2010). This study sought to understand the challenges of Latino immigrant families within an antiimmigrant sociopolitical environment.

Cecilia Ayón, MSW, Ph.D., and David Becerra, MSW, Ph.D., are both Assistant Professors in the School of Social Work at Arizona State University in Phoenix. The research team would like to thank the participants for sharing their experiences and making this research possible. This research was funded by the Silberman Fund Faculty Grant Program.

Copyright @ 2013 Advances in Social Work Vol. 14 No. 1 (Spring 2013), 206-228 


\section{Socio-Political Context in Arizona Impacting Latino Families}

A plethora of anti-immigrant legislations have passed at both the state and federal levels and have impacted the well-being of Latino immigrants and their families. Arizona has been at the forefront in anti-immigrant legislation. Although the Personal Responsibility and Work Opportunity Reconciliation Act (PRWORA) of 1996 specifically prohibited undocumented immigrants access to public services (PRWORA; U.S. Public Law 104-193), the state of Arizona passed Proposition 200 in 2004 which requires proof of immigration status/ID when applying for public benefits (i.e., Medicaid/ACCCS, housing assistance, and TANF). State employees are also mandated to report anyone who is suspected to be undocumented to immigration officials, with failure to report leading to misdemeanor charges (Furman, Langer, Sanchez, \& Negi, 2007).

Arizona has also passed several bills that impact the education of Latino and immigrant students throughout the state. Despite previous studies that indicated the benefits of bilingual education (Combs, Evans, Fletcher, Parra, \& Jiménez, 2005; Mora, 2000), Proposition 203 was passed in 2000. Proposition 203 eliminated bi-lingual education and segregated children who were English Language Learners. Proposition 300 passed in 2006, requires university students who are not U.S. citizens or permanent residents to pay out-of-state-tuition and eliminates their eligibility for financial aid. House Bill 2281 passed in 2011, which banned Mexican-American studies in Arizona.

The Legal Arizona Workers Act (AKA Employers Sanctions policy) was passed in 2008. In accordance with this act, the state of Arizona requires the use of e-verify to validate immigration statuses of all newly hired employees, and the state has the power to revoke or suspend business licenses if a company knowingly hires an undocumented worker. Although this policy is meant to sanction businesses that hire undocumented immigrants, few have been sanctioned, and instead the immigrant workers have been subjected to worse treatment. Evidence suggests that employers are using this policy to conduct exploitive practices, such as withholding payment or reducing pay rates significantly, while still requiring individuals to work the same number of hours, if not more (Ayón, Gurrola, Moya-Salas, Androff, \& Krysik, 2012). Since there are limited job prospects, such individuals have to endure these exploitive practices in order to support their families.

Arizona Senate Bill 1070 (SB1070) passed in 2010, requires individuals to carry documentation at all times and defines failure to do so as a crime. State and local police officers are also permitted to check the immigration status of individuals they suspect are undocumented (Pew Hispanic Center, 2010). In 2012, three of the major provisions of SB1070 were struck down, but the U.S. Supreme court upheld the "show me your papers requirement." That is, police officers may question people's immigration status if reasonable suspicion is present (Liptak, 2012). Meanwhile, since 2006 the Maricopa County Sheriff's department has carried out "Crime Suppression Activities" or community/workplace raids in order to identify and detain undocumented immigrants. 


\section{Latino Family Well-being and Immigration}

\section{Family Disintegration}

It is estimated that 6-in-10 Latinos worry that they (themselves), a family member, or close friend will be deported (Pew Hispanic Center, 2010). There are an estimated 5.5 million children with undocumented parents, approximately three quarters of whom are U.S. citizens (Chaudry et al., 2010). Deportations of parents presents a serious risk to children's immediate safety, economic security, and well-being, as children are separated from their parents during critical stages of development (Chaudry et al., 2010). As a result of parent-child separation, children experience changes in eating and sleeping patterns, excessive crying and clinging to parents, and aggressive and withdrawn behaviors (Chaudry et al., 2010).

\section{Barriers to Health Care}

Immigrants experience many challenges in accessing health care and thus are less likely to utilize medical/social services than native-born individuals (Kullgren, 2003; Vega, Kolody, Aguilar-Gaxiola, \& Catalano, 1999). Access to care is severely limited by Latinos lack of health insurance. Latinos have the lowest level of health insurance coverage in the United States. More specifically, 57\% of foreign-born Mexicans lack health insurance (Saenz, 2010). Many Latino immigrant families are unable to afford health insurance (Cristancho, Garces, Peters, \& Mueller, 2008), are ineligible for employer-sponsored insurance (Pitkin Derose, Bahney, \& Lurie, 2009), or do not understand different aspects of insurance policies (Cristancho et al., 2008).

Individuals who have Limited English Proficiency (LEP) encounter another set of challenges in accessing care (Cristancho et al., 2008; Pitkin Derose et al., 2009). Language access is part of organizational cultural competency (Hilfinger Messias, McDowell, \& Estrada, 2009). Access to bilingual providers, trained interpreters, translated written materials, and cultural and linguistic competency trainings for all staff are necessary to provide culturally competent services (Hilfinger Messias et al., 2009). Evidence suggests interpreters are often unavailable or poorly trained (Cristancho et al., 2008) and confronted with ethical dilemmas during practice (Cristancho et al., 2008; Hilfinger Messias, et al., 2009). LEP impacts the quality of care, increases the risk of misdiagnosis (Hilfinger Messias et al., 2009; Ku \& Flores, 2005; Ku \& Matani, 2001; Pitkin Derose et al., 2009; Viladrich, 2006), and may exclude them from or delay receiving services (Suleiman, 2003).

\section{Discrimination}

The experience of discrimination among Latinos has been exacerbated with the passage of anti-immigrant legislation. A 2009 study revealed that Americans perceived Latinos as the ethnic group that is most often subjected to discrimination (Pew Hispanic Center, 2010). Perceptions of discrimination vary among Latinos with $70 \%$ of foreignborn Latinos and $49 \%$ of native born Latinos viewing discrimination against Latinos as a major problem (Lopez, Taylor, \& Morin, 2010). Concomitantly, Latinos are subjected to

racial profiling as assumptions and judgments are made about their documentation status 
based on their appearance and English proficiency. Discrimination occurs at multiple levels. The implementation of policies or practices can marginalize or prevent whole communities from participating in society (Mullaly, 2002). Micro-aggressions are "brief and commonplace daily verbal, behavioral, and environmental indignities...that communicate hostile, derogatory, or negative racial slights and insults” (Sue et al., 2008, p. 330).

Nier, Gaertner, Nier, and Dovidio (2012) drew from antidiscrimination law and social psychological research in their analysis of SB1070 and the fair enforcement of its statues. They found that the ambiguity innate to what constitutes "reasonable suspicion" of unlawful presence in the United States, "paired with a lack of comprehensive training and ineffective testing procedures for detecting discrimination will likely result in many Latinos being illegally targeted on the basis of their race” (p. 1). Furthermore, in their investigation of the Maricopa County Sherriff's Office (MCSO), the U.S. Department of Justice Civil Rights Department found that Latinos were subject to racial profiling and discriminatory practices (Perez, 2011). The report states that the MCSO's deputies, supervisory staff, and command staff engaged in racial profiling of Latinos including unlawful stops, detentions, and arrests of Latinos; and unlawful retaliation against individuals who complain about or criticize MCSO's policies or practices. In addition, "crime suppression activities" or raids were often initiated in communities based on biasinfected indicators, such as individuals with "dark skin" or "individuals were speaking Spanish” (Perez, 2011).

Discrimination has deleterious effects on the well-being of Latino immigrant families. Perceived and actual discrimination prevents Latino immigrants and LEP individuals from accessing care and impacts their quality of care (Keller, Silberberg, Hartmann, \& Michener, 2010). In addition, substantial evidence links discrimination to indicators of poor physical and mental health among immigrants and children of immigrants (Ayón, Marsiglia, \& Parsai, 2010; Ding \& Hargraves, 2009; Umaña-Taylor \& Updegraff, 2007; Williams, Neighbors, \& Jackson, 2008). For example, chronic vigilance for discrimination may result in chronic stress and this can be detrimental to one's health (Brosschot, Gerin, \& Thayer, 2006; Williams \& Mohammed, 2009). Sawyer, Major, Casad, Townsend, and Berry Mendes (2012) found that Latinas who anticipated prejudice experienced cardiovascular stress and increased psychological distress.

Among Latino youth discrimination has been found to impact their educational process and has also been linked to anti-social behavior. Foreign-born and native-born Latino youth reported discrimination in their school context from teachers, white children, and horizontal discrimination or within group discrimination (Córdova \& Cervantes, 2010). Instances of discrimination included lower expectations by teachers, assuming gang membership or problematizing of Latino/LEP youth, and name calling. Adolescence is a challenging time for any youth and when compounded by perceived/actual discrimination, youths' health is placed at risk. After controlling for factors associated with antisocial behaviors, perceived discrimination remained a robust predictor of antisocial behavior among Latino youths with the odds of antisocial behavior nine times higher when youths reported discrimination (Rivera et al., 2011). 
This study examined the challenges Latino immigrant families encounter within an anti-immigrant social-political environment.

\section{Methods}

\section{Focus Groups}

Focus groups were used to obtain information on Mexican parents' perceptions on factors impacting families' well-being. Focus groups are often used with ethnic and lowincome communities because they are communitarian in style, stimulate dialogue among participants, and often feel safer than one-on-one interviews (Genttlemen \& Winkleby, 2000; Linhorst, 2002). Seven focus groups were held at a community-based agency where participants received services. The focus groups were facilitated by the lead author, and trained research assistants attended the sessions as note takers and observers. The focus groups' sessions ranged in duration from 1.5 to 2.0 hours. Focus group data was collected between April and October 2010.

\section{Sampling Procedures and Recruitment}

The participants were recruited from a Family Literacy Program in Arizona. Following human subjects approval, the first author informed potential participants about the research project including the purpose of the study, confidentiality, potential risks and benefits, and eligibility criteria (i.e., first generation Latino parents with young children). The participants received $\$ 25$ remuneration to partially compensate for their time.

\section{Participants}

Fifty-two, first-generation immigrants/migrants participated in the focus group sessions. The sample consisted predominantly of mothers $(n=45,86.5 \%)$ and one focus group that included only fathers $(n=7,13.5 \%)$. The participants' mean age was 36 years $(S D=8.058)$ and each had an average of 3 children $(S D=1.223)$. The majority of the participants were married $(n=36,69.2 \%)$ or living together $(n=8,15.4 \%)$ and the remaining were single ( $n=5,9.6 \%)$ or reported their status as 'other' $(n=2,3.8 \%)$. Over half of the participants had annual incomes below $\$ 19,999$ ( $n=28$ or 54\%). Most of the participants were Mexican ( $n=50,96.2 \%$ ), one participant was born in the United States. and raised in Mexico, and another participant was from South America. Participants had resided in the U.S. an average of 11 years $(S D=5.690)$.

\section{Interview Guide}

A semi-structured interview guide was used to facilitate the focus group dialogue. Several topics were discussed including familial and community strengths, family needs and challenges, support networks, and services needed to promote family well-being. For the purpose of this study, we focused on participants' stories on the needs and challenges experienced by families. Participants were asked for examples and probing questions were used as needed. A short demographic survey was also completed. Data was collected in Spanish and translated for the purpose of this study. 


\section{Data Analysis}

The procedures outlined by Straus and Corbin (1990) were used to analyze the focus group data. The transcripts were (re)read, labeled, and categorized using open and axial coding. Open coding involved identifying and labeling each distinct incident or idea; categorizing the data by grouping concepts that represented similar phenomena; labeling or naming the categories; and developing properties and dimensions of the identified categories. In axial coding, connections between the categories and subcategories are made. Axial coding contextualizes the properties of the phenomenon by identifying the causal conditions by which the phenomenon is manifested and examining the consequences of the phenomena. Throughout the analysis, a constant comparative approach was used within and between focus group transcripts (Charmaz, 2006; Strauss \& Corbin, 1990).

Several steps were taken to enhance the trustworthiness of the study. The analysis was completed by the lead author and one trained research assistant, who discussed major themes and interpretations. The researchers referred back to transcripts whenever inconsistencies in the analysis emerged and discussed our understanding of participants' comments. In addition, two additional focus groups were held to complete member checks with a randomly selected subgroup of participants $(n=15)$. During the member checks, findings from the preliminary analysis were presented to the participants for their feedback on whether the findings were consistent with their experiences (Armour, Rivaux, \& Bell, 2009). Participants' feedback was incorporated into the final analysis. Finally, in order to support the credibility of the findings, quotes were used extensively (Charmaz, 2005).

\section{Findings}

Participants were asked to comment on the major challenges confronting Latino immigrant families. The three overarching challenges shared by participants were discrimination, uncertainty, and a lack of jobs. At the root of the challenges faced by Latino immigrant families were recent anti-immigrant legislation (i.e., SB1070) and the economic crisis that is confounded further by their status as immigrants. Participants experiences of discrimination, uncertainty, and a lack of jobs impacted their lives in multiple ways. They described high levels of stress/depression and fear among all family members, family instability, and barriers to accessing care/assistance.

\section{Economy - No Jobs}

Pues yo creo que ahorita con la crisis económica casi no hay trabajo. Casi no hay trabajo y cuando hay no te lo dan por problemas de papeles o lo pagan muy barato. [Well, I think that right now, with the economic crisis there is very little work. There is very little work, and if there is work, they won't give it to you because you don't have papers, or if they do, they pay you really low].

Participants' comments reflect statistics indicating that Latinos experience a higher unemployment rate compared to the general population, $11 \%$ vs. $8.2 \%$ respectively 
(Bureau of Labor Statistics, 2012). In addition, it is believed that foreign-born Latinos may be the segment most adversely impacted by the recession (Tan, 2010).

La gente se estresa porque no hay trabajo. [People are stressed because there is no work].. También por falta de trabajo muchas familias se están desuniendo porque los señores se están yendo a otros estados o está quedando uno solo de mujer...o matrimonios se está deshaciendo. [And, also, because of the lack of work, there are a lot of families that are becoming less united because the men are going to other states or there are a lot of single moms left...or marriages are splitting up.]

Individuals who are employed are often enduring abusive working conditions where they are asked/forced to work more and are not compensated. This finding has been reflected in other studies following the implementation of the Employers Sanction policy (Ayón et al., 2012).

\section{Discrimination}

Hacen falta leyes que pidan respeto para los Latinos porque hay mucha gente grosera...pues sería la discriminación. [There is a need for laws that ask for more respect towards Latinos because there are a lot of people who are rude...well, it is discrimination.]

Participants reported experiencing discrimination at an institutional and individual level. Incidents of discrimination included discrimination based on limited English proficiency (LEP), horizontal discrimination, micro-aggressions, and racial profiling.

Institutional level discrimination. Immigration policies are becoming progressively harsher restricting the day-to-day functioning of Latino families who are confronted by discriminatory practices through their interactions with various institutions. At an institutional level, participants reported being discriminated against by police, educators, and social services providers whose behaviors often reflect racial profiling.

Participante 1: Los policías casi la mayoría también son racistas. Si ven a una persona en cualquier carro no más que le vean cara de Mexicano, de ilegal, lo paran por cualquier cosa y piden documentos que a veces yo creo que no tienen que pedir. Eso, eso le da inseguridad a uno y ellos saben el temor que le está dando a uno por eso también digo el racismo de parte de los policías ellos saben con que atemorizar a uno y lo hacen. El Sheriff te para hasta por un foco fundido, por un vidrio quebrado o por cualquier cosa. $Y$ eso ya es un delito grande para ellos y un problemón más grande para uno que se tiene que regresar. [Most of the police are also racists. If they see someone in a car that kind of looks Mexican, an illegal, they stop you for whatever reason and they ask for your documents. That sometimes, I think they don't need to ask for, and that's what causes insecurity. And they know the fear they are causing, so that's why I say that exists racism from police, they know how to scare you, and they do what they do. The sheriff will stop you even for a broken light, for a broken 
window or anything else. And that is a big crime for them now, but an even bigger problem for those that have to go back [home country].

Participant 2: Ese es el pretexto de ellos para pararte y poderte pedir, que te identifiques y para empezar un, para poder reportar a la gente y pedirte documentos. Si no lo tienes te piden el otro o bajo cualquier pretexto con tal de esposarte. [That is the excuse they use to stop you and ask you to identify yourself and so they can start, so they can report you and ask you for your documents. If you don't have it they ask you for another one and under whatever pretext as long as they take you in.]

Participant 1: Por eso te digo mientras para ellos es, es algo fácil mientras para uno es un problemón que se le viene encima. ¿Y ahora que voy hacer, y ahora que voy hacer? [That's what I'm saying, for them it's easy meanwhile for us it's a huge problem. And what am I going to do? What am I going to do?]

These quotes illustrate racial profiling where participants feel assumptions are made based on their appearance. The use of racial profiling to implement SB1070 is one of the major arguments held against this policy. Racial profiling is already evident as found by the U.S. Department of Justice investigation of the MCSO (Perez, 2011). Furthermore, individuals who experience such treatment often do not know who to turn to for assistance.

Participants described the impact of discrimination by police officers and educators toward their children. Before, children aspired to be police officers and teachers, because these individuals represented people who would assist them in a time of need. However, now, children fear these individuals.

Participante 1: Si tu miras unos años atrás la policía eran los héroes de los niños todos los niños querían ser policía. Ahora...miran a un policía y tienen aquel miedo porque dicen te va a llevar la policía...están perdiendo la confianza en la policía....If you look a few years back the police were the heroes, all children wanted to be policemen. Now... they look at a policeman and they have that fear that the police will take you away... they're losing faith in the police.]

Participante 2: Y los maestros tienen mucho que ver porque...por ejemplo mis sobrinitas en la escuela...la maestra le dijo, 'a todos los Mexicanos los van a sacar de este país,” entonces ellos son niños y empiezan agarran ideas...ellos no saben ni que ni nada y digo yo entonces que tipo de maestros son ellos de educar...... [And the teachers have a lot to do with that... for example, my nieces in their school,... a teacher said, "they are going to kick all Mexicans out of the country." They are children and they start to get ideas... They don't know what is right or wrong, and I think, what kind of teachers are they to educate...]

Participante 3: Ya las personas que confiaban las criaturas que son los maestros...y los policías...ahora lo niños tienen miedo. [And now the people that children used to trust, like teachers... and the police... now they are scared of them.] 
In addition to fearing individuals who used to represent help (i.e. police officers and educators), children are exposed to hostile environments where they are bullied in school and tormented by teachers.

Es que los maestros como dijo ella también están exponiendo sus ideas que tienen. Mi hija va a la high school y cuando firmaron la ley dijo que una maestra hispana dijo 'pues yo estoy en acuerdo con esta ley porque ninguna persona indocumentada paga impuestos.' Le digo a mi hija, le digo pues si con el trabajo de tu papa que pagamos casa, víveres, comemos más o menos, a veces compramos ropa nueva. Le digo y cuando va a ser sus impuestos él todavía tiene que pagar aparte de lo que le están quitando. Como no vamos a pagar impuestos. Tienen una idea muy errónea. Mhm, muy mal le digo de la realidad que nosotros estamos viviendo. [Teachers at school, like she said, are also voicing their ideas. My daughter goes to high school and when they passed the law, she said one of her Hispanic teachers said, 'well I'm in favor of the law because not one undocumented immigrant pays taxes.' I told my daughter, I told her that, with her dad's job, we pay taxes, rent, groceries we eat decently, sometimes we buy new clothes. I added, and when he goes and does his taxes he has to pay extra from what they are already taking away. How would we not pay taxes? They have the wrong idea. Mhm, quite different, I tell her, from the reality we are living.]

Another participant shared,

Participante 1: ...cada quien vive la discriminación [...everybody lives in discrimination.]

Participante 2: De los mismos compañeros...escuchan lo que oyen en casa van y lo dicen en la escuela con los niños que no son de su misma raza, los que no hablan completamente bien el Inglés, que no sea su color, por muchas razones. La discriminación vive y ahora que tienen la idea de separar Hispanos con Americanos. [From the same classmates... they hear what they say at home and they go and say it at school with the children that aren't from their same race, the ones that don't speak English fluently, that aren't their same color, for a lot of reasons. There is a lot of discrimination and now that they have the idea to separate Hispanics and Americans.]

Participante 1. Eso les va afectar muchísimo, muchísimo, muchísimo a ellos. [That is going to affect them so very, very, very much.]

As described by participants, schools are becoming hostile sites where teachers make inappropriate comments and children are bullied. This is no longer an environment conducive to learning for Latino children.

Language was reflected in most of the stories shared by participants. Participants were aware that their inability to speak English prevented them from actively participating in U.S. society as shared by one parent who said that it impacts her ability to participate in her child's education. 
Sabe también a veces si uno no habla Inglés se detiene mucho de participar en las cosas de las escuelas de los niños....Va a reuniones [con los maestros] y muchas veces no hay traducciones... y uno muchas veces prefiere no ir a juntas ni nada de eso porque no entiende....Entonces... no participa uno en las escuelas ni en los eventos de los niños en las escuelas. [You know, also sometimes, if one doesn't speak English, you hesitate to participate in things involving the children's school... You go to meetings [with the teachers] and a lot of the times there aren't any translators... and a lot of the time, one prefers to not go to the meetings at all because one doesn't understand... So... you don't participate in school things or the children's school events.]

Although most participants were enrolled in a literacy program and were in the process of learning English, their limited English skills were not enough. Participants reported that they were confronted with service providers, such as the Arizona Health Care Cost Containment System (AHCCCS), who refused to speak in Spanish even when they were able to speak Spanish. Language barriers impact their ability to access services, health care being one of them.

Participant A: Em pues hay personas por ejemplo a mí me ha tocado...ver en AHCCCS que [entre los trabajadores] la mayoría habla Inglés, Inglés y algunos trabajadores habla español. Y a veces llega gente hablando español y dicen [los trabajadores] que no saben [hablar español]. Entonces he visto mucha gente así que trata de no ayudar a la gente o hacerlas menos. [Um, well, there are people that I have seen for example...in AHCCCS that [among the employees] the majority of them speak English, and some employees speak Spanish. Sometimes people come in talking Spanish and they say [the employees] that they don't know [how to speak Spanish]. So I have seen a lot of people that try to not help or make them feel less [because they can't speak English].

Participant C: Y en cualquier lado, en todos los lados es así. [And everywhere, it's like that everywhere.]

Participant B: Y aunque hablen Español no quieren hablar español [con uno] y uno se siente todo cohibido. [And even if they speak Spanish, they don't want to speak Spanish [to you], and you feel inhibited.]

[Participant A: Um well there are people that I have seen for example...in AHCCCS that [among the employees] the majority of them speak English and some employees speak Spanish. Sometimes people come in talking Spanish and they say [the employees] that they don't know [how to speak Spanish]. So I have seen a lot of people that try to not help or make them feel less [because they can't speak English].

Participant C: And everywhere, it's like that everywhere.

Participant B: And even if they speak Spanish they don't want to speak Spanish [to you] and you feel inhibited. ] 
In many examples shared by participants, it was front line workers who function as gate keepers to health care services who refused to speak in Spanish or to get an interpreter to assist. The following participant stated that she continuously had to advocate for herself because although she is a U.S. citizen she was often refused services or treated poorly because she did not speak English well.

A mí me pasa muchísimo simplemente por no hablar Inglés siempre pido traductor, pero siempre me están discriminando. Yo he reportado muchos doctores. Cuando estaba embarazada me pasó...que no me querían atender y simplemente el doctor me decía es que traes plan de emergencia, AHCCCS de emergencia....Yo soy ciudadana Americana...digo yo no debería de tener que hacer eso....Yo siempre les alego. Cuando yo fui a reportar ese doctor le dije a mi no me importa que yo sea indocumentada a mi me dan el servicio porque me lo tiene que dar. Le dije aunque esta tarjeta sea de emergencia...ese no es problema de él. Él tiene que dar su servicio porque a él le van a pagar aunque sea AHCCCS de emergencia....Osea muchísima discriminación. [It happens to me a lot simply for not speaking English. I always ask for a translator, but they always discriminate against me. I have reported many doctors. It happened to me when I was pregnant... They didn't want to see me, and the doctor would simply say 'you only have an emergency plan, AHCCCS for emergencies...' I'm an American citizen... I mean, I shouldn't have to go through that... I always argue with them. When I went to report that doctor, I told them that I don't care [even if] I was undocumented, you give me the services, because you have to give it to me. I told them that even if this card is just for emergencies...that is not his problem. He has to provide me with his service because they are going to pay him, even if it is AHCCCS for emergencies... So, there is so much discrimination.]

Fortunately, this participant was able to advocate for herself and knew she had rights. This is not always the case. As stipulated by the Emergency Medical Treatment Act of 1986, hospitals that accept Medicare payments are required to treat persons seeking emergency care and cover the costs if patients are unable to pay or have no insurance (Dolgin \& Dieterich, 2010). Hospitals have found caring for undocumented immigrants economically disadvantageous, and as a result, have turned to contracting with private agencies that will deport such patients (Dolgin \& Dieterich, 2010; Sullivan \& Zayas, in press). For example, it is estimated that St. Joseph's Hospital in Phoenix Arizona repatriates 96 immigrants each year (Sontag, 2008).

Individual level discrimination. Participants also reported discrimination at an individual level; that is, in their interactions with community members, including Latinos who were residents/citizens (horizontal discrimination) and other ethnic/racial groups. Participants' narratives revealed experiences of micro-aggressions in the use of verbal or behavioral racial slights and insults (Sue et al., 2008).

Discrimination based on LEP was carried into participants' descriptions of discrimination at an individual level. Instances of horizontal discrimination were often 
shared during the focus groups. The division among Latinos, based on citizenship and immigration status, was often challenging for participants.

Discriminación hacia la misma gente y luego lo peor de todo es que la gente Latina es la peor. Los que tienen papeles son los peores, no digo que todos pero si mucha gente son bien racistas. Si se ha fijado ahora en las marchas de todo eso los que apoyan la ley esa son más Latinos, más Chicanos, apoyando la ley más que gabachos, que afro-americanos. Son más Latinos que dicen 'Váyanse."...Incluso no son que hayan nacido aquí, que se hicieron después residentes o que después se hicieron ciudadanos son los que andan mas, haciendo discriminación. [Discrimination against the same people, and what's worse is that the Latino people are the worst. The people that have their papers are the worst. I'm not saying all of them, but a lot of people are very racist. If you saw in the recent protests about all of this, the ones that support the law are more Latinos, more Chicanos, supporting the law than whites, or African-Americans. There are more Latinos saying, 'Leave.'...In fact, it's not the ones that were born here, [its] the ones that later became residents, or later became citizens, are the ones doing more discrimination \{discriminating\}.]

In the following quote, a participant shares another example of horizontal discrimination, and her quote illustrates that the passage of anti-immigrant policies have also reduced the tolerance for difference among communities in general. The standards that the participant is being held to (i.e., to speak English without an accent) also reflect instances of micro-aggressions.

$Y$ yo he notado mucha diferencia porque he tenido mis propias experiencias porque trabajo de cajera ahí en la tienda 99. Y antes de que entrara esta ley...la gente era más amable....Y ahora que entro esa ley, yo he notado que la gente no quiere hablar Español. La gente Latina yo la saludo en Español...y no me contestan en Español. Sé que me entienden porque me responden lo que les estoy preguntando pero me responded en Inglés y ya no quieren hablar Español. Es rara la gente que llega y me habla Español, todos mucho Inglés Inglés Inglés Inglés. Y los gabachos o morenos también desde que entro esa ley si quieres platicar con ellos, decirles algo, saludarlos o si me preguntan algo y yo no sé responderles bien en Inglés y a la primera palabra que me equivoqué me dicen 'Do you speak English?' Ya me discriminan y ya que ven que más o menos hablas te hacen mala cara...o dicen que quieren hablar con otro. $Y$ antes yo notaba que era diferente ellos también trataban a la vez de comunicarse con uno mismo y ahora ya a la primera le tuerce la cara a uno. [I have noticed a lot of difference because I have my own experiences, because I work as a cashier at the 99 cent store. Before this law was passed... people were a lot nicer... and now that the law passed, I have noticed that people don't want to speak Spanish anymore. I greet Latinos in Spanish... and they don't answer in Spanish. I know they understand me, because they reply to what I'm asking, but they answer in English, and they don't want to talk in Spanish. It is rare that people who come will speak to me in Spanish. Everybody is English, English, English, English, and white or brown, ever since that law was passed. When you want to talk to 
them, or tell them something, or greet them, or if they ask me something, and I don't know how to respond correctly in English, and the first time I make a mistake they ask, 'Do you speak English?' And they discriminate against me, and if they see that you kind of speak English, they give you a dirty look...or they say they want to talk to someone else. And before, I would notice that it was different, they would also try to communicate with you, and now at the first mistake, they give you a smug face.]

Participants noted that such policies impacted how Latinos were treated. Participants often felt humiliated and reported a lack of respect for Latinos. Individuals were treated as second-class citizens or lesser beings, a form of micro-aggressions (Sue et al, 2008).

Como ahora por lo de esta ley que si el mismo gobierno está haciendo que la gente nos falte el respeto, nos tratan peor que animales. Yo digo que valoran más a un perro que a uno. Porque si ven a uno perro ahí tirado lo levantan y lo llevan a curar y a uno no. [Now because of this law, the government itself is making people disrespect us. They treat us worse than animals. I say, they value a dog more than one of us. Because if they see a dog lying there, they pick it up and take it to be healed, and they don't do that for us.]

\section{Uncertainty}

Participants live in a constant state of uncertainty. What will happen with the immigration legislation? What will happen with the economy? What will happen to our children if we cannot access health care for them? What will happen to our children if we do not return home one day? These are common questions participants raised throughout the focus groups. The degree of uncertainty in their lives seemed to be the most stressful aspect of their situations.

Participante 1: Yo pienso que ahorita a nosotros todos los Hispanos...tenemos un futuro incierto. Porque nadie sabemos...yo tengo tiempo que tengo como dos semanas que estoy así, no sé, no sé qué va a pasar, no sé que voy hacer. Pero sí me pongo a pensar y si me voy? Y si no? Y digo si me quedo y de verdad me pasa algo? Te pones a pensar que tenemos un futuro incierto porque nadie, ni el que se va no tiene la culpa ni el que se queda tampoco. [I think that right now, all Hispanics... we have an uncertain future. Because none of us know. I have [for] some time, like two weeks [been] thinking like, that I don't know what's going to happen, I don't know what I'm going to do. But I start thinking, if I leave? If I don't? What if I stay, and something does happen? You start thinking, we have an uncertain future because it's no ones, not the one that leaves or the ones that stay's, fault.]

Participante 2: es un sentimiento, el sentimiento que lo que tú sientes te hace reaccionar. El miedo...[it's a feeling, the feeling that you get that makes you react. The fear...]

The uncertainty of their futures created much stress in their lives and participants often stated that they just needed some tranquility. - necesitamos tranquilidad. To 
illustrate the degree of uncertainty experienced by Latino individuals who may be undocumented, or have undocumented family members, consider the chronology of SB1070. We ask the reader to imagine how one feels when one (or one's family member) is waiting to hear back about the results regarding a potentially life-threatening disease. Now consider experiencing those feelings for a time period exceeding two years. From January 2010 to June 2012, Latino families have been awaiting the final ruling on SB1070.

\section{Impact on Families}

Stress and depression. The economic crisis and anti-immigrant legislation impacts families' health. Participants stated that they were depressed, as a result of the recent antiimmigrant legislation. It manifested through their inability to sleep and eat, and carry on with daily activities.

Participant X: Yo pienso que nos está dando hasta depresión, nos estamos enfermando. Depresión por esta ley...[I think we are even falling into depression, that we are getting sick...depression because of this law...]

Participant AR: uh si. [oh yes.]

Participant A: Yo me he sentido mal, hay veces que a mí no me dan ganas de nada. [I have been feeling bad. There are times when I don't feel like doing anything at all.]

Participant AN: Ni de bañarse. [Not even of showering.]

Particpant XX: no tiene uno fuerzas. [You don't have the strength.]

Participant A: Hay mucha gente que se ha deprimido yo me incluyo porque si, a veces que estoy bien y otros días que estoy con una tristeza y más que si a diario estas escuchando las noticias, en las noticias que cada día más gente se va.... [There are a lot of people who have fallen into depression, including me, because yes, sometimes, I'm okay, and other days, I have a sadness, and even more so if you are listening to the news daily. On the news every day, more and more people leave...]

Participants stated that the economic conditions they have endured also heightened the level of stress experienced in their households. Parents have had to work hard to not lash out at their children or significant others.

Family instability. As stated earlier, many fathers left their families in search of work, and, as a result, families were disintegrating. At the same time, participants reported that parents who did have jobs, often had to work all day leaving their children alone. Participants went on to say that even when children were left alone, the family was still barely making ends meet.

Participante 1: ¿Sabe lo que ahorita está pasando mucho? Que como muchas personas no tienen trabajo, están preocupadas y se descuidan de los niños porque uno como adulto dice, que voy hacer mañana? ¿Que voy hacer o voy a 
salir, voy a buscar trabajo? Los niños se quedan solos hay veces que en la casa y luego...[Do you know what's happening a lot now? Well, a lot of people don't have jobs. They are worried and they neglect their children, because one, as an adult, says, what am I going to do tomorrow? What am I going to do, or am I going to go out and look for a job? The children stay alone sometimes at home and then...]

Participante 2: La frustración, la frustración. [The frustration, the frustration.]

Participante 1 continua: Empiezan ellos[los hijos] a sentir, dicen que caso tiene seguir en la escuela o que caso tiene esto o que caso tiene lo otro. Y ahí es donde empiezan ya los jovencitos a salirse de la escuela, juntarse con malas compañías y esa es una de las cosas que ahorita. O la soledad de ellos, o que los adultos nos metemos en tantas cosas que...[They [the children] begin to feel, to say, what's the point of staying in school, or what's the point of this, or what's the point of that. And it starts, that is, when the kids begin to drop out of school, hanging out with a bad crowd, and that is one of the things happening now. Or their loneliness, or that we, adults, are so busy with things that...]

Participante 2: O por lo mismo, por el trabajo no estar en la casa uno. [Or for the same reason, because of their jobs they aren't home.]

Participante 3: Por tener trabajo y por no tenerlo. [Because of work and because of not having work.]

Participante 2: Y por no tenerlo. [And for not having it.]

Participante 1: Porque cuando tienen trabajo muchas veces tienen que trabajar todo el día y no tienen tiempo para los hijos. [Because when you have a job, sometimes you are working all day and you don't have time for your children.]

Fear. Fear impacted the whole family. Participants feared that if SB1070 was implemented as proposed, they would be at risk of multiple forms of abuse. One concern that has been prominent in the critique of SB1070 is that women in domestic violence situations who are undocumented will not seek help from police, placing them and their children at greater risk (Spence, 2010).

No deje que no vamos a llamar a la policía - vamos hacer abusados totalmente, van a entrar a las casas, nos va a asaltar. Van a ver...todas clases de abuso porque ya saben ellos tanto como morenos y blancos y de todas las razas ya saben que no vamos a poder hablarles a la policía. O sea vamos a ser víctimas ....We aren't going to call the police... We are going to be completely abused. They are going to go into our homes. They are going to assault us. There are going to be... all kinds of abuse, because they know, no matter what, brown, white, or whatever race, we won't be able to call the police. So we are going to be the victims...]

Children of all ages were aware that there were unsafe places for their families and they feared leaving their homes and what their futures would bring. Consider the following quote: 
“...íbamos cada rato a Wal-Mart. Y ya después, 'mija vamos a Wal-Mart?' 'No mama ya no vamos a ir,' dice 'ahí está el sheriff.' Tres años y es no mas lo que escucha en las noticias y nosotros que platicamos..." [We used to go to Wal-Mart all the time. Then afterwards, 'want to go to Wal-mart?' 'No mom, we aren't going anymore' she says 'the sheriff is there.' She is three years old and she knows just by hearing the news and us talk...]

Another participant stated, Mi niña me pregunta también, tiene ocho años, me dijo un día, '¿mami cuando yo crezca y si ese señor sigue ahí también me puede hacer lo mismo?’ Porque yo le dije tu estas chiquita a ti no te puede hacer, ... ‘¿pero cuando yo crezca también me va a pasar?' ósea ellos están atemorizados. [My daughter also asked me — she's eight years old-one day she asked me, 'mommy when I grow up and that man is still there, can he also do that to me?' Because I told her that since she's little, nothing can happen to her 'but when I grow up it will happen?' So they are terrified.]

Barriers to care. As a result of discrimination and economic conditions, families experienced many barriers to health care. Families experienced high levels of stress, fear, and depression. At the same time, they were unable to access care due to their documentation status or LEP status. This was a major concern as often, children who are U.S. citizens are denied services. The following quote illustrates the inconsistency in the implementation of proposition 200.

Participante 2: porque me quitaron el AHCCCS. Yo no soy de aquí pero mi hija es de aquí y no puedo aplicar para AHCCCS por no tener ID. [Because they took my AHCCCS away, I'm not from here, but my daughter is, and I can't apply for AHCCCS, because I don't have an ID.]

Participante 5: ¿quién te dijo eso? [Who told you that?]

Participante 2: si esa ley esta desde el año pasado o antepasado [Yes, that law is from last year, or the year before...]

Participante 5: déjame te digo que estas en un error porque yo no aplicaba para AHCCCS por los ingresos de mi esposo ahora [que se quedo mi esposo sin trabajo] tuvimos que aplicar. Y fuimos aprobados y para nada me pidieron identificación y... [Let me tell you that you are mistaken, because I didn't qualify for AHCCCS because of my husband's income, and now, my husband was laid off, and we had to apply. We were approved, and they didn't ask me for identification, and...]

Participante 2: a muchos según los mismos trabajadores si veían que no tenías ID del estado de Arizona, ellos mismos te mandan a migración. Eso salía hasta en las noticias y puede ser que no sea cierto pero si crea miedo porque mucha gente ya no aplicó. [To a lot of people, if the employees saw that you didn't have ID from the state of Arizona, they themselves would send you to immigration. That even came out on the news, and it might not be true, but it does create fear in a lot of people, because a lot of them haven't applied.] 


\section{Discussion and Implications}

The economic crisis has impacted most people living in the United States, but studies have shown that Latinos have been more negatively impacted by the crisis than other groups (Bureau of Labor Statistics, 2012; DeNavas-Walt \& Smith, 2011). Many politicians have portrayed undocumented immigrants as a drain on federal and state resources, and, as a result, an increased number of anti-immigration bills have been passed. SB1070 has cost Arizona hundreds of millions of dollars in lost revenue (Lacayo, 2011; National Association of Elected and Appointed Officials, n.d.) and exacerbated the problems many Latino immigrants face such as discrimination, poverty, and access to quality health care, education, and employment.

The findings of this study highlight the challenges that immigrant Latino families in Arizona face as a result of the current economic and political conditions. The participants expressed the confusion, sadness, frustration, and fear that they feel and how their children share these feelings as well. Understanding how the current economic and political environment impacts Latino immigrants has important implications for policy makers and social service providers. Policy makers need to consider not just the economic consequences of a policy, but the social consequences as well. The participants indicated that they feared immigration enforcement as a result of new immigration policies. Studies have found that fear of deportation for an individual or his/her loved ones can lead to mental health issues, particularly stress and anxiety (Cavazos-Rehg, Zayas, \& Spitznagel, 2007; Potochnick \& Perreira, 2010). The stress, anxiety, and depression that can result from constant fear of deportation only exacerbate the stress associated with adapting to a new country and culture (Finch \& Vega, 2003).

The recent anti-immigrant policies and increased enforcement of immigration policies, as well as negative depictions of Latino immigrants in the U.S. media, have led to greater feelings of discrimination among Latino immigrants (Becerra et al., 2010). Participants indicated they had encountered increased discrimination since the passage of new immigration policies, including horizontal discrimination from documented Latinos, instances of micro-aggressions, and institutional discrimination. These findings are significant as discrimination is associated with negative health and social implications. For example, Ayón and colleagues (2010) found that Latino youths who had higher levels of perceived discrimination reported higher levels of internalized emotional issues, such as anxious and withdrawn depressive symptoms. In addition, perceived and actual discrimination can have a negative impact on Latino immigrant families because their hope for a better life may be replaced by a sense of isolation and marginalization (Finch, Kolody, \& Vega, 2000; Hancock, 2005).

The marginalization of immigrant communities should also be a major concern for policy makers and social service workers. If a community is marginalized and people are excluded from meaningful participation in society, then not only will health and safety issues persist, but residents will never be able to achieve self-actualization. Participants described how the anti-immigrant policies and enforcement of such policies have instilled fear and affected their daily lives. One participant described how her three-year-old daughter was afraid to go to Wal-Mart for fear of being apprehended by the sheriff. If 
families fear being apprehended and avoid conducting normal daily activities such as going to the store or interacting with others, then this will increase the social isolation of Latino immigrant families (Capps, Castaneda, Chaudry, \& Santos 2007).

The strategies used to enforce immigration policies also played a role in increasing social isolation, as immigrant families feared being apprehended by police officers or being reported by social service providers - individuals who are meant to provide help and support. Police officers and service providers were no longer trusted, yet serve as gate keepers to needed services. Such efforts to enforce immigration policies have been found to deter political, social, and cultural integration of Latino immigrant communities (Romero, 2008). Instead of fostering a sense of safety, the increased presence of police and immigration authorities and patrols in Latino immigrant neighborhoods may have created a sense of fear and anxiety of constantly being pursued, as well as an increased mistrust of police (Menjivar \& Bejarano, 2004). Furthermore, participants in this current study expressed concern that anti-immigrant policies and enforcement were actually creating a dangerous situation for immigrants, especially immigrant women. If Latino immigrants are fearful of apprehension and deportation, they may be hesitant to call police to report crimes, placing Latino immigrants at greater risk of being victims of crimes.

The findings of this study highlight the negative health and social implications that the economic crisis and immigration policies and enforcement have had on Latino immigrant families. Undocumented immigrant communities were already isolated from the majority population, and, despite the Supreme Court ruling striking down much of SB1070, anti-immigrant policies and enforcement strategies continue to affect immigrant families and entire communities. For example, although President Obama initiated the Deferred Action for Childhood Arrivals, which allows undocumented immigrants who came to the United States as children to apply for a two-year temporary work permit, Jan Brewer, the Governor of Arizona, signed an executive order which prohibits individuals who received work permits through Deferred Action from receiving state benefits, instate tuition, or even drivers' licenses. These inconsistent and often contradictory policies leave families in a state of fear and confusion, which may cause undocumented immigrant parents of U.S. citizen children to avoid applying for services their children are eligible to receive, for fear of being apprehended by immigration authorities.

Policy makers must understand that there are consequences that negatively impact people beyond the intended economic gains of targeting undocumented immigrants. In addition, social service agencies and practitioners must be informed and prepared to work with Latino immigrant families under these current conditions. If people perceive that they are targets of discrimination and fear deportation, then even individuals in need of services may avoid seeking care from community and social service agencies. Avoiding care, even in times of need, may create further health disparities between Latinos and Whites in the United States and lead to increased economic costs (Berk \& Schur, 2001).

Social service agencies may not be prepared to work with Latino immigrant communities because they lack bilingual/bicultural practitioners and staff. For example, Martinez-Brawley and Zorita (2011) argue that, in addition to language barriers, social 
work curricula do not adequately prepare future social workers to work with immigrant populations. Education for helping professions must do more to reflect the changing demographics of the United States and prepare practitioners to work with immigrant populations. Community-based organizations must recruit, hire, and train bilingual/bicultural practitioners and staff to work with Latino immigrant communities. It is also important that community-based organizations incorporate cultural and community strengths into social service delivery and community development efforts. Community-based organizations should partner with public health officials, and state and county social service agencies to conduct outreach and education efforts regarding immigrant rights, as well as help address the fear and anxiety that Latino immigrant families face in this current economic and political climate.

Future research is needed to further understand the impact of anti-immigrant policies and sentiment on Latino and immigrant families, including the various forms of discrimination and oppressive circumstances experienced by immigrant families as a result of such policies. In particular, close attention is needed to examine the long term impact of discrimination on Latino and immigrant children. In addition, research is needed to understand how helping professions are addressing the needs of this community and navigating oppressive legislation.

\section{References}

Armour, M., Rivaux, S. L., \& Bell, H. (2009). Using context to build rigor. Qualitative Social Work, 8(1), 101-122. doi:10.1177/1473325008100424

Ayón, C., Gurrola, M., Moya-Salas, L., Androff, D., \& Krysik, J. (2012). Intended and unintended consequences of the employer sanction law on Latino families. Qualitative Social Work, 11(6), 587-603.

Ayón, C., Marsiglia, F., \& Parsai, M. (2010). Latino family mental health: Exploring the role of discrimination and familismo. Journal of Community Psychology, 38(6), 742756.

Becerra, D. (2012). The impact of anti-immigration policies and discrimination in the U.S. on migration intentions among Mexican adolescents. International Migration, 50(4), 20-32.

Becerra, D., Gurrola, M., Ayón, C., Androff, D., Krysik, J., Gerdes, K.,... Segal, E. (2010). Poverty and other factors affecting migration intentions among adolescents in Mexico. Journal of Poverty, 14(1), 1-16.

Berk, M. L., \& Schur, C. L. (2001). The effect of fear on access to care among undocumented Latino immigrants. Journal of Immigrant Health, 3(3), 151-156.

Brosschot, J. F., Gerin, W., \& Thayer, J. F. (2006). The perseverative cognition hypothesis: A review of worry, prolonged stress-related physiological activation, and health. Journal of Psychosomatic Research, 60(2), 113-124.

Bureau of Labor Statistics. (2012). Economic news release: Employment situation summary. Retrieved from http://www.bls.gov/news.release/empsit.nr0.htm 
Capps, R., Castaneda, R. M., Chaudry, A., \& Santos, R. (2007). Paying the price: The impact of immigration raids on America's children. Washington, DC: Urban Institute.

Cavazos-Rehg, P. A., Zayas, L. H., \& Spitznagel, E. L. (2007). Legal status, emotional well-being and subjective health status of Latino immigrations. Journal of the National Medical Association, 99(10), 1126-1131.

Charmaz, K. (2006). Constructing grounded theory: A practical guide through qualitative analysis. London: Sage Publications.

Chaudry, A., Capps, R., Pedroza, J. M., Castañeda, R. M., Santos, R. \& Scott, M. M. (2010). Facing our future. Children in the aftermath of immigration enforcement. The Urban Institute. Retrieved from http://www.urban.org/UploadedPDF/412020_FacingOurFuture_final.pdf

Combs, M. C., Evans, C., Fletcher, T., Parra, E., \& Jiménez, A. (2005). Bilingualism for children: Implementing a dual language program in an English-only state. Educational Policy, 19(5), 701-728.

Córdova, D., \& Cervantes, R. C. (2010). Intergroup and within-group perceived discrimination among U.S.-born and foreign-born Latino youth. Hispanic Journal of Behavioral Sciences, 32(2), 259-274.

Cristancho, S., Garces, D. M., Peters, K. E., \& Mueller, B. C. (2008). Listening to rural Hispanic immigrants in the Midwest: A community-based participatory assessment of major barriers to health care access and use. Qualitative Health Research, 18(5), 633-646.

DeNavas-Walt, C., Proctor, B. D., \& Smith, J. C. (2011). Income, poverty, and health insurance coverage in the United States: 2010. Retrieved from http://www.census.gov/prod/2011pubs/p60-239.pdf

Ding, H., \& Hargraves, L. (2009). Stress-associated poor health among adult immigrants with a language barrier in the United States. Journal of Immigrant \& Minority Health, 11(6), 446-452.

Dolgin, J. L., \& Dieterich, K. R. (2010). When others get too close: Immigrants, class, and the health care debate. Cornell Journal of Law and Public Policy, 19(2), 283334.

Finch, B. K., Kolody, B., \& Vega, W. A. (2000). Perceived discrimination and depression among Mexican-origin adults in California. Journal of Health and Social Behavior, 41(3), 295-313.

Finch, B. K., \& Vega, W. A. (2003). Acculturation stress, social support, and self-rated health among Latinos in California. Journal of Immigrant Health, 5(3), 109-117.

Furman, R., Langer, C. L., Sanchez, T. W., \& Negi, N. (2007). A qualitative study of immigration policy and practice dilemmas for social work students. Journal of Social Work Education, 43(1), 133-146. 
Genttlemen, L., \& Winkleby, M. A. (2000). Using focus groups to develop a heart disease prevention program from ethnically diverse, low-income women. Journal of Community Health, 25(6), 439-454.

Grieco, E. M. (2010). Race and Hispanic origin of the foreign-born population in the United States: 2007. Retrieved from http://www.census.gov/prod/2010pubs/acs11.pdf

Hancock, T. U. (2005). Cultural competence in the assessment of poor Mexican families in the rural Southwest United States. Child Welfare, 85(5), 689-711.

Hilfinger Messias, D. K., McDowell, L., \& Dawson Estrada, R. (2009). Language interpreting as social justice work: Perspectives of formal and informal healthcare interpreters. Advances in Nursing Science, 32(2), 128-143.

Humes, K. R., Jones, N. A., \& Ramirez, R. R. (2011). Overview of race and Hispanic origin: 2010. Retrieved from http://www.census.gov/prod/cen2010/briefs/c2010br02.pdf

Keller, S. C., Silbergerg, M., Hartmann, K. E., \& Michener, J. L. (2010). Perceived discrimination and use of health care services in a North Carolina population of Latino immigrants. Hispanic Health Care International, 8(1), 4-13.

Ku, L., \& Matani, S. (2001). Left out: Immigrants' access to health care and insurance. Health Affairs, 20(1), 247-256.

Ku, L., \& Flores, G. (2005). Pay now or pay later: Providing interpreter services in health care. Health Affairs, 24(2), 435-444.

Kullgren, J. T. (2003). Restrictions on undocumented immigrants' access to health services: The public health implications of welfare reform. American Journal of Public Health, 93(10), 1630-1633.

Lacayo, A. E. (2011). One year later: A look at SB1070 and copycat legislation. National Council of La Raza. Retrieved from http://issuu.com/nclr/docs/alookatsb1070v3

Linhorst, D. M. (2002). A review of the use and potential of focus groups in social work research. Qualitative Social Work, 1(2), 208-228.

Liptak, A. (2012, June 25). Blocking parts of Arizona law, justices allow its centerpiece. The New York Times. Retrieved from http://www.nytimes.com/2012/06/26/us/supreme-court-rejects-part-of-arizonaimmigration-law.html?_r=2\&pagewanted=all

Lopez, M. H., Taylor, P., \& Morin, R. (2010). Illegal immigration backlash worries, divides Latinos. Washington, DC: Pew Hispanic Center. Retrieved from http://pewhispanic.org/files/reports/128.pdf

Martinez-Brawley, E. E., \& Zorita, P. M. B. (2011). Immigration and human services: The perils of professionalization. Families in Society, 92(2), 133-137. 
Menjivar, C., \& Bejarano, C. (2004). Latino immigrants' perceptions of crime and police authorities in the United States: A case study from the Phoenix-Metropolitan area. Ethnic \& Racial Studies, 27(1), 120-148.

Mora, J. (2000). Policy shifts in language-minority education: A mismatch between politics and pedagogy. The Educational Forum, 64(3), 204-214.

Mullaly, B. (2002). Challenging oppression: A critical social work approach. Toronto, Canada: Oxford University Press.

National Association of Elected and Appointed Officials. (n.d.). Not in our state: Lessons from Arizona. Retrieved from http://www.naleo.org/sb1070toolkit/SB\%201070\%20Copycat\%20Tool\%20Kit.pdf

Nier, J. A., Gaertner, S. L., Nier, C. L., \& Dovidio, J. F. (2012). Can racial profiling be avoided under Arizona immigration law? Lessons learned from subtle bias research and anti-discrimination law. Analyses of Social Issues and Public Policy, 12(1), 5-20. doi:10.111/j.1530-2415.2011.01248.x

Perez, T. E. (2011). United States' investigation of the Maricopa County Sheriff's Office. U.S. Department of Justice, Civil Rights Division. Retrieved from http://www.justice.gov/crt/about/spl/documents/mcso findletter 12-15-11.pdf

Personal Responsibilities and Work Opportunity Reconciliation Act (1997). U.S. Public Law 104-193. Retrieved from http://www.fns.usda.gov/snap/rules/Legislation/pdfs/PL_104-193.pdf

Pew Hispanic Center. (2010). Hispanics and Arizona's new immigration law. Retrieved from http://pewresearch.org/pubs/1579/arizona-immigration-law-fact-sheet-hispanicpopulation-opinion-discrimination.

Pitkin Derose, K., Bahney, B. W., \& Lurie, N. (2009). Immigrants and health care access, quality, and cost. Medical Care Research and Review, 66(4), 355-408.

Potochnick, S. R., \& Perreira, K. M. (2010). Depression and anxiety among first generation Latino youth: Key correlates and implications for future research. Journal of Nervous and Mental Disease, 198(7), 470-477.

Romero, M. (2008). Go after the women: Mothers against illegal aliens' campaign against Mexican immigrant women and their children. Indiana Law Journal, 83(4), 1355-1389.

Rivera, F., López, I., Guarnaccia, P., Ramirez, R., Canino, G., \& Bird, H. (2011). Perceived discrimination and antisocial behaviors in Puerto Rican children. Journal of Immigration and Minority Health, 13(3), 453-461.

Saenz, R. (2010). Latinos in America 2010: Population Bulletin Update. Washington, DC. Retrieved from http://www.prb.org/pdf10/latinos-update2010.pdf

Sawyer, P. J., Major, B., Casad, B. J., Townsend, S. S. M., \& Berry Mendes, W. (2012). Discrimination and the stress response: Psychological and physiological 
consequences of anticipating prejudice in interethnic interactions. American Journal of Public Health, 102(5), 1020-1026.

Sontag, D. (2008, August 3). Immigrants facing deportation by US hospitals. The New York Times. Retrieved from http://www.nytimes.com/2008/08/03/us/03deport.html?pagewanted=all

Spence, G. (2010). SB 1070: A review of the impact on immigrant victims of domestic violence in Arizona. Retrieved from http://ssrn.com/abstract=1686033

Strauss, A. L., \& Corbin, J. M. (1990). Basics of qualitative research: Grounded theory procedures and techniques. Newbury Park, CA: Sage Publications.

Sue, D. W., Nadal, K. L., Capodilupo, C. M., Lin, A. I., Torino, G. C., \& Rivera, D. P. (2008). Racial microaggressions against Black Americans: Implications for counselors. Journal of Counseling \& Development, 86(3), 330-338.

Suleiman, L. P. (2003). Beyond cultural competence: Language access and Latino civil rights. Child Welfare, 82(2), 185-200.

Sullivan, J. E., \& Zayas, L. E. (2012). Passport biopsies: Hospital deportations and implications for social work. Manuscript submitted for publication.

Tan, C. (2010, May 6). Hispanics’ unemployment rate soars. Retrieved from http://articles.latimes.com/2010/may/06/business/la-fi-latino-jobless-20100506

Umaña-Taylor, A. J., \& Updegraff, K. A. (2007). Latino adolescents’ mental health: Exploring the interrelations among discrimination, ethnic identity, cultural orientation, self-esteem, and depressive symptoms. Journal of Adolescence, 30(4), 549-567.

Viladrich, A. (2006). Latino immigrant health in the US: A growing field amidst unraveling challenges. Journal of Latino-Latin American Studies, 2(2), 125-139.

Vega, W. A., Kolody, B., Aguilar-Gaxiola, S., \& Catalano, R., (1999). Gaps in service utilization by Mexican Americans with mental health problems. The American Journal of Psychiatry, 156(6), 928-934.

Williams, D. R., Neighbors, H. W., \& Jackson, J. S. (2008). Racial/ethnic discrimination and health: Findings from community studies. American Journal of Public Health, 98(Supplement), S29-S37.

Williams, D. R., \& Mohammed, S. A. (2009). Discrimination and racial disparities in health: Evidence and needed research. Journal of Behavioral Medicine, 32(1), 20-47.

\section{Author note:}

Address correspondence to Cecilia Ayón, MSW, Ph.D., School of Social Work, 411 N. Central Ave., Suite 800, Phoenix, Arizona, 85004-0689. Email: cecilia.ayon@asu.edu 